\title{
PREDIKSI JUMLAH HOTEL DAN RESTAURANT TUTUP AKIBAT DAMPAK COVID-19 MENGGUNAKAN BACKPROPAGATION DAN ADAPTIVE NEURO FUZZY
}

\author{
Dinita Rahmalia' ${ }^{1)}$, M. Yusak Anshori' ${ }^{2)}$, Teguh Herlambang ${ }^{3)}$, Denis Fidita Karya ${ }^{4)}$ \\ ${ }^{1)}$ Universitas Islam Darul Ulum Lamongan \\ Jl. Airlangga 3 Sukodadi Lamongan \\ ${ }^{2,3,4)}$ Universitas Nahdlatul Ulama Surabaya \\ Jl. Jemursari Surabaya \\ e-mail: dinitarahmalia@gmail.com ${ }^{1}$, yusak.anshori@unusa.ac.id ${ }^{2)}$,teguh@unusa.ac.id ${ }^{3)}$
}

\begin{abstract}
ABSTRAK
Corona Virus Disease (Covid-19) telah menjadi bencana dunia karena menyerang banyak korban di seluruh dunia dan mengakibatkan kematian. Karena virus tersebut menyerang di beberapa negara termasuk Indonesia, pemerintah Indonesia membuat keputusan untuk menutup hotel dan restaurant sebagai pencegahan Covid-19. Pada penelitian ini, metode prediksi akan dilakukan menggunakan Backpropagation dan Adaptive Neuro Fuzzy. Pada prediksi jumlah hotel dan restaurant yang tutup menggunakan Backpropagation dan Adaptive Neuro Fuzzy, dibutuhkan beberapa input seperti jumlah korban di Jakarta, jumlah korban di Indonesia, dan jumlah korban di dunia. Backpropagation dan Adaptive Neuro Fuzzy dapat menghasilkan prediksi jumlah hotel dan restaurant yang tutup mendekati nilai target. Simulasi diterapkan dengan membagi dataset ke dalam data training (80\%) dan data testing (20\%). Dari simulasi Backpropagation, Backpropagation dapat menghasilkan prediksi jumlah hotel dan restaurant yang tutup pada data training dengan optimal RMSE adalah 9,2422 dan data testing dengan optimal RMSE adalah 8,9419. Dari simulasi Adaptive Neuro Fuzzy, Adaptive Neuro Fuzzy dapat membuat prediksi jumlah hotel dan restaurant yang tutup pada data training dengan optimal RMSE adalah 0,5324 dan testing data dengan optimal RMSE adalah 5,3198.
\end{abstract}

Kata Kunci: Backpropagation, Adaptive Neuro Fuzzy, Covid-19, Prediksi

\begin{abstract}
Corona Virus Disease (Covid-19) have become the world attentions because they have attacked many people in the world and many victims are die. Because these diseases have spreaded in many countries including Indonesia, the Indonesia goverment make the some rules to close the hotels and restaurants for preventing the spread of Covid-19. In this research, estimation method will be done by Backpropagation Neural Network. In making estimation of the number of closed hotels and restaurants using Backpropagation Neural Network, it is required some inputs such as the number of victims in Jakarta, the number of victims in Indonesia, and the number of victims in the world. Backpropagation Neural Network can make estimation of the number of closed hotels and restaurants approaching target. Simulations are applied by splitting dataset into training data (80\%) and testing data (20\%). From Backpropagation Neural Network simulations, Backpropagation Neural Network can make estimation of the number of closed hotels and restaurants in training data with optimal RMSE is 9.2422 and testing data with optimal RMSE is 8.9419. From ANFIS simulations, ANFIS can make estimation of the number of closed hotels and restaurants in training data with optimal RMSE is 0.5324 and testing data with optimal RMSE is 5.3198.
\end{abstract}

Keywords: Backpropagation, Adaptive Neuro Fuzzy, Covid-19, Prediction

\section{Pendahuluan}

Pada awal tahun 2020, Corona Virus Disease (Covid-19) telah menjadi bencana dunia karena menyerang banyak korban di seluruh dunia dan mengakibatkan kematian. Virus ini pertama kali ditemukan di China dan menyebar di seluruh dunia termasuk Indonesia. Covid-19 adalah penyakit yang disebabkan oleh Corona virus yang menyerupai SARS sehingga dinamakan SARS-CoV2. Gejala dari penyakit ini adalah deman, lemas, batuk kering, sakit tenggorokan, dan sesak nafas.

Karena penyakit ini telah menyebar di berbagai negara termasuk Indonesia, maka pemerintah Indonesia membuat keputusan untuk menutup hotel dan restaurant sebagai pencegahan Covid-19. Jakarta adalah salah satu kota di Indonesia dimana terdapat korban pertama dan kota dengan paling banyak korban positive Covid-19. Karena itu, prediksi jumlah hotel dan restaurant tutup di Jakarta sangat penting dilakukan. Pada penelitian ini, metode prediksi akan dilakukan menggunakan Backpropagation dan Adaptive Neuro Fuzzy.

Backpropagation sebagai bagian dari Neural Network terdiri dari propagasi maju, propagasi mundur, dan mengupdate matriks bobot. Pada propagasi maju, komputasi menggunakan fungsi aktivasi dimulai dari input, hidden layer, dan output secara berurutan. Pada propagasi mundur, komputasi factor error diterapkan dari output, hidden layer, dan input secara berurutan. Setelah itu matriks bobot dapat diupdate [7]. 
Adaptive Neuro Fuzzy adalah jaringan yang menggunakan algoritma supervised learning. Algoritma ini pengembangan dari Takagi-Sugeno fuzzy inference system model. Jaringan adaptive memiliki karakteristik yang berisi sejumlah adaptive nodes. Setiap node memiliki fungsi yang berbeda dan output dipengaruhi dari sinyal dan parameter. Adaptive Neuro Fuzzy menggunakan hybrid method untuk melatih consequent parameter dan premise parameter [9].

Pada penelitian sebelumnya, model prediksi telah diterapkan menggunakan exponential smooting pada produksi [1], Kalman Filter pada estimasi harga saham [10], ARIMA untuk peramalan nilai tukar petani [2], fuzzy logic untuk prediksi intensitas matahari [14]. Backpropagation telah diterapkan pada prediksi cuaca [3],[13], prediksi korban penyakit ebola [4], prediksi harga smartphone [8],[11]. Adaptive Neuro Fuzzy telah diterapkan pada prediksi cuaca [5] dan prediksi harga minyak dunia [12]. Algoritma ini diterapkan pada data training dan data testing dengan proporsi tertentu. Pada penelitian ini, Backpropagation dan Adaptive Neuro Fuzzy akan digunakan untuk memprediksi jumlah hotel dan restaurant tutup di Jakarta. Pada prediksi jumlah hotel dan restaurant yang tutup menggunakan Backpropagation dan Adaptive Neuro Fuzzy, dibutuhkan beberapa input seperti jumlah korban positive Covid-19 di Jakarta, jumlah korban meninggal di Jakarta, jumlah korban positive Covid-19 di Indonesia, jumlah korban meninggal di Indonesia, jumlah korban positive Covid-19 di dunia, jumlah korban meninggal di dunia.

Dari simulasi Backpropagation, Backpropagation dapat menghasilkan prediksi jumlah hotel dan restaurant yang tutup pada data training dengan optimal RMSE adalah 9,2422 dan data testing dengan optimal RMSE adalah 8,9419. Dari simulasi Adaptive Neuro Fuzzy, Adaptive Neuro Fuzzy dapat membuat prediksi jumlah hotel dan restaurant yang tutup pada data training dengan optimal RMSE adalah 0,5324 dan testing data dengan optimal RMSE adalah 5,3198.

\section{AlgORITMA BACKPROPAGATION}

Backpropagation adalah jenis Neural Network yang sering digunakan pada proses prediksi. Backpropagation terdiri dari beberapa input $x_{1}, x_{2}, \ldots, x_{n}$, hidden layer $z_{1}, z_{2}, \ldots, z_{p}$, dan beberapa output $y_{1}, y_{2}, \ldots, y_{m}$. Bobot $v_{i j}$ menghubungkan input $x_{i}$ menuju hidden layer $z_{j}$. Bobot $w_{j k}$ menghubungkan hidden layer $z_{j}$ menuju output $y_{k}$ - Pada Backpropagation, terdapat tiga fase perhitungan seperti propagasi maju, propagasi mundur, dan update matriks bobot [7]. Jaringan Backpropagation dapat dilihat pada Gambar 1.

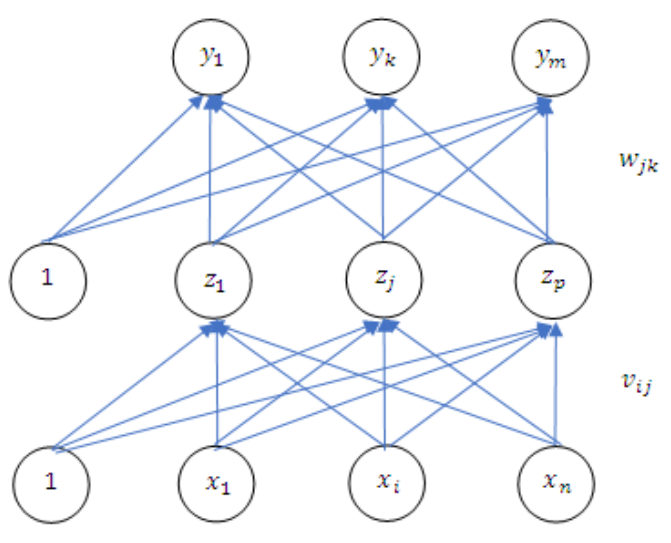

Gambar. 1. Jaringan Backpropagation

Algoritma Backpropagation adalah :

Inisialisasi matrik bobot $V$ and $W$ dengan bilangan acak antara -0.5 sampai 0.5 .

$e=1$

while $\left(e \leq\right.$ max_epoch \& \&MSE $\left.\geq \min _{-} M S E\right)$

for $(d=1:$ datasize $)$

1. Setiap nput menerima sinyal dan menghubungkan pada setiap hidden layer melalui propagasi maju pada (3) sampai (6) dan propagasi mundur pada (7) sampai (11).

Propagasi Maju 
INDEXIA: Informatic and Computational Intelegent Journal

Dinita Rahmalia, M. Yusak Anshori, Teguh Herlambang, Denis Fidita Karya - Prediksi Jumlah Hotel Dan Restaurant Tutup Akibat Dampak Covid-19 Menggunakan Backpropagation Dan Adaptive Neuro Fuzzy

2. Output $z_{j}, j=1,2, . ., p$ dihitung pada hidden layer pada (4)

$$
\begin{gathered}
z_{-} n e t_{j}=v_{o j}+\sum_{i=1}^{n} x_{i} v_{i j} \\
z_{j}=f\left(z_{-} n e t_{j}\right)=\frac{1}{1+e^{-z_{-} n e t_{j}}}
\end{gathered}
$$

3. Hitung $y_{k}, k=1,2, \ldots, m$ pada (6)

$$
\begin{gathered}
y_{-} n e t_{k}=w_{0 k}+\sum_{j=1}^{p} z_{j} w_{j k} \\
y_{k}=f\left(y_{-} n e t_{k}\right)=\frac{1}{1+e^{-y_{-} n e t_{k}}}
\end{gathered}
$$

Propagasi Mundur

4. Hitung output factor $\delta$ berdasarkan error pada setiap output $y_{k}, k=1,2, \ldots, m$

$$
\delta_{k}=\left(t_{k}-y_{k}\right) f^{\prime}\left(y_{-} n e t_{k}\right)
$$

5. Hitung perubahan bobot

$$
\Delta w_{j k}=\alpha \delta_{k} z_{j}, \quad k=1,2, . ., m j=0,1,2, . ., p
$$

6. Hitung factor $\delta$ hidden layer pada (10) berdasarkan error di setiap hidden layer $z_{j}, j=1,2, \ldots, p$

$$
\begin{gathered}
\delta_{-} n e t_{j}=\sum_{k=1}^{m} \delta_{k} w_{j k} \\
\delta_{j}=\delta_{-} n e t_{j} f^{\prime}\left(z_{-} n e t_{j}\right)
\end{gathered}
$$

7. Hitung perubahan bobot

$$
\Delta v_{i j}=\alpha \delta_{j} x_{i}, \quad j=1,2, \ldots, p i=0,1,2, \ldots, n
$$

Update Matriks bobot

8. Update matriks bobot baru

$$
\begin{gathered}
w_{j k}=w_{j k}+\Delta w_{j k} \\
v_{i j}=v_{i j}+\Delta v_{i j}
\end{gathered}
$$

end

Hitung Root of Mean Square Error (RMSE)

$$
R M S E=\sqrt{\frac{1}{\text { datasize }} \sum_{d=1}^{\text {datasize }} \frac{1}{m} \sum_{k=1}^{m}\left(T_{d k}-Y_{d k}\right)^{2}}
$$

dengan $T_{d k}$ adalah nilai target dan $Y_{d k}$ adalah output.

$e=e+1$

end

\section{AlgORITMA AdAPTIVE NeURo FuZZY}

Diagram of Adaptive Neuro Fuzzy terdiri dari lima layer dan dapat dikonstruksi seperti Gambar 2. 


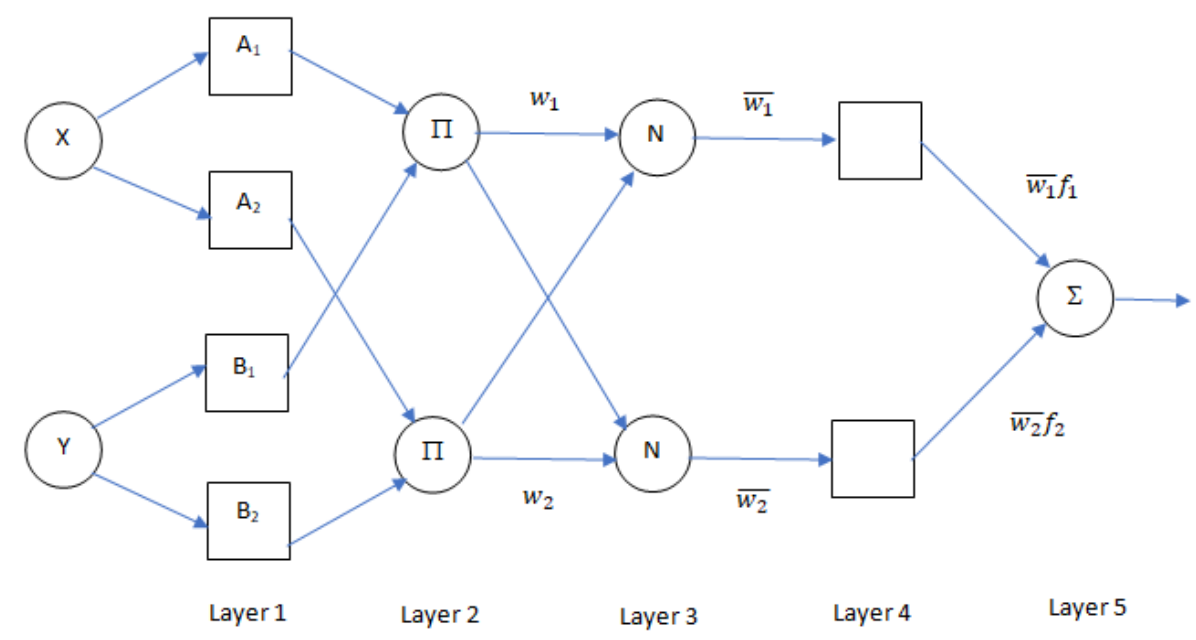

Gambar. 2. Jaringan Adaptive Neuro Fuzzy

Terdapat dua input $x$ dan $y$, dan satu output $f$. Misalkan rule yang digunakan adalah :

Rule 1 : Jika $x$ adalah $A_{1}$ dan $y$ adalah $B_{1}$ maka $f_{1}=p_{1} x+q_{1} y+r_{1}$

Rule 2 : Jika $x$ adalah $A_{2}$ dan $y$ adalah $B_{2}$ maka $f_{2}=p_{2} x+q_{2} y+r_{2}$

dengan $A_{1}, A_{2}$ dan $B_{1}, B_{2}$ adalah fungsi keanggotaan. Parameter $p_{1}, q_{1}, r_{1}$ dan $p_{2}, q_{2}, r_{2}$ adalah consequent parameter.

Setiap layer dari Adaptive Neuro Fuzzy memiliki perhitungan yang berbeda yang diberikan pada (15) sampai (19) sebagai berikut [9] :

Layer 1. Pada layer ini, setiap node memiliki parameter fungsi. Output pada setiap node adalah derajat keanggotaan dari fungsi keanggotaan.

$$
\begin{gathered}
\mathrm{O}_{1, i}=\mu_{A i}(x) i=1,2 \\
\mathrm{O}_{1, i}=\mu_{B i-2}(y) i=3,4
\end{gathered}
$$

Fungsi keanggotaan yang digunakan adalah Gaussian membership $\mu(x)=\exp \left(-\left(\frac{x-c}{a}\right)^{2}\right)$ atau generalized bell membership $\mu(x)=\frac{1}{1+\left(\frac{x-c}{a}\right)^{2 b}}$. Parameter $a, b, c$ dari fungsi keanggotaan adalah parameter premise.

Layer 2. Pada layer ini, node output adalah hasil perkalian antara sinyal dan dikirim menuju node berikutnya.

$$
\mathrm{O}_{2 i}=w_{i}=\mu_{A i}(x) * \mu_{B i}(y) i=1,2
$$

Layer 3. Setiap node adalah rasio antara the bobot ke-i dengan jumlah seluruh bobot.

$$
\mathrm{O}_{3 i}=\overline{w_{i}}=\frac{w_{i}}{\sum_{i} w_{i}} i=1,2
$$

Layer 4. Setiap node adalah fungsi pada (18)

$$
\mathrm{O}_{4 i}=\overline{w_{i}} f_{i}=\overline{w_{i}}\left(p_{i} x+q_{i} y+r_{i}\right) i=1,2
$$


INDEXIA: Informatic and Computational Intelegent Journal

Dinita Rahmalia, M. Yusak Anshori, Teguh Herlambang, Denis Fidita Karya - Prediksi Jumlah Hotel Dan Restaurant Tutup Akibat Dampak Covid-19 Menggunakan Backpropagation Dan Adaptive Neuro Fuzzy

Layer 5. Setiap node menjumlahkan semua sinyal dari node sebelumnya.

$$
\mathrm{O}_{5}=\sum_{i} \overline{w_{i}} f_{i}
$$

\section{HASIL DAN PEMBAHASAN}

Dataset diperoleh dari data hotel dan restaurant yang tutup selama 1 Maret 2020 sampai 30 April 2020 (61 hari), yang diterbitkan oleh Indonesian Hotel and Restaurant Association, dengan area yang diobservasi adalah Jakarta sebagai kota pertama dimana Covid-19 pertama kali ditemukan. Data tersebut akan diprediksi menggunakan Backpropagation dan Adaptive Neuro Fuzzy.

Selain itu, terdapat data tambahan yaitu data jumlah korban Covid-19 (positive and meninggal) di Jakarta selama 1 Maret 2020 sampai 30 April 2020, yang diperoleh dari website resmi Covid-19 Jakarta, data jumlah korban Covid-19 (positive and meninggal) di Indonesia selama 1 Maret 2020 sampai 30 April 2020, yang diperoleh dari Kementerian Kesehatan Republik Indonesia, dan data jumlah korban Covid-19 (positive dan meningga) di dunia selama 1 Maret 2020 sampai 30 April 2020, yang diperoleh dari Worldometer website. Data tersebut akan digunakan sebagai input pada Backpropagation dan Adaptive Neuro Fuzzy, dengan output adalah jumlah hotel dan restaurant tutup di Jakarta selama 1 Maret 2020 sampai 30 April 2020.

\section{A. Data Covid-19}

Grafik jumlah hotel dan restaurant tutup selama 1 Maret 2020 sampai 30 April 2020 (61 hari) di Jakarta dapat dilihat pada Gambar 3.

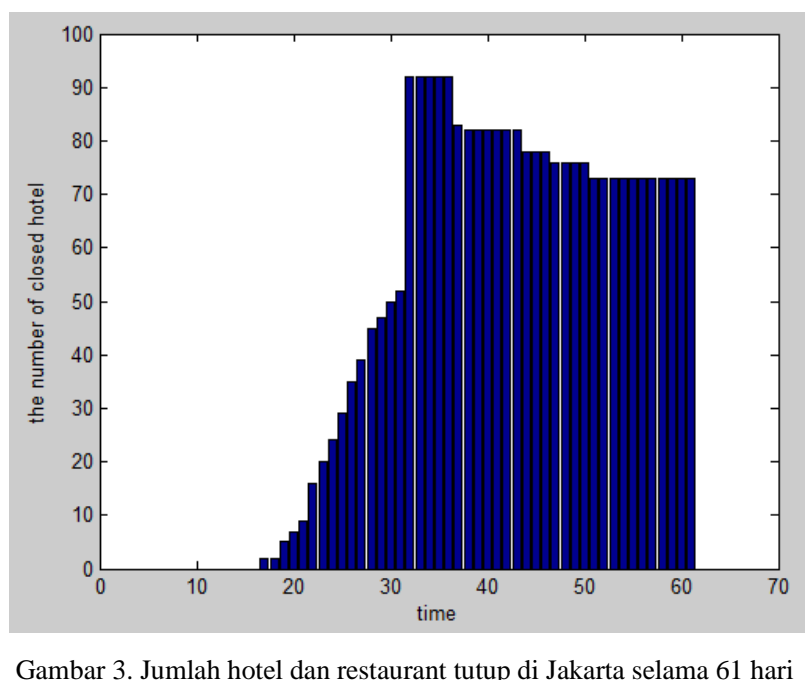

Untuk memprediksi jumlah hotel dan restaurant yang tutup menggunakan Backpropagation dan Adaptive Neuro Fuzzy sebagai output (y), diperlukan beberapa input seperti jumlah korban yang positive Covid-19 di Jakarta $\left(x_{1}\right)$, jumlah korban meninggal di Jakarta $\left(x_{2}\right)$, jumlah korban yang positive Covid-19 di Indonesia $\left(x_{3}\right)$, jumlah korban meninggal di Indonesia $\left(x_{4}\right)$, jumlah korban yang positive Covid-19 di dunia $\left(x_{5}\right)$, dan jumlah korban yang meninggal di dunia $\left(x_{6}\right)$.

Grafik jumlah korban Covid-19 di Jakarta selama 1 Maret 2020 sampai 30 April 2020 dapat dilihat pada Gambar 4(a). Terdapat dua bagian dari grafik dengan warna yang berbeda, yaitu korban yang positive dan korban yang meninggal. Grafik jumlah korban Covid-19 di Indonesia selama 1 Maret 2020 sampai 30 April 2020 dapat dilihat pada Gambar 4(b). Terdapat dua bagian dari grafik dengan warna yang berbeda, yaitu korban yang positive dan korban yang meninggal. Grafik jumlah korban Covid-19 di dunia selama 1 Maret 2020 sampai 30 April 2020 dapat dilihat pada Gambar 4(c). Terdapat dua bagian dari grafik dengan warna yang berbeda, yaitu korban yang positive dan korban yang meninggal. 
INDEXIA: Informatic and Computational Intelegent Journal

Dinita Rahmalia, M. Yusak Anshori, Teguh Herlambang, Denis Fidita Karya - Prediksi Jumlah Hotel Dan Restaurant Tutup Akibat Dampak Covid-19 Menggunakan Backpropagation Dan Adaptive Neuro Fuzzy

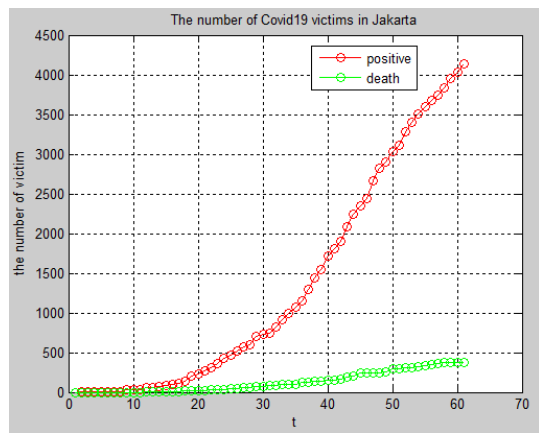

(a)

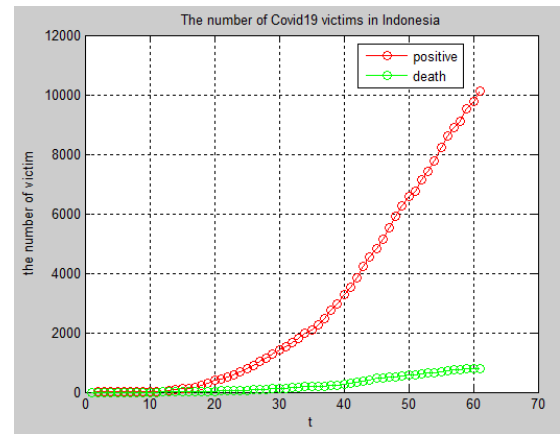

(b)

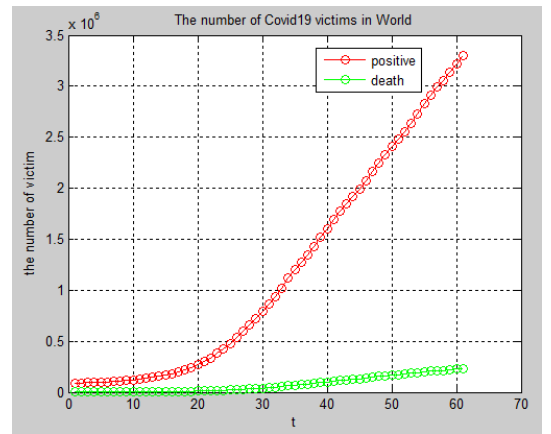

(c)

Gambar 4. Jumlah korban positive dan meninggal karena Covid-19 (a) Di Jakarta (b) Di Indonesia (c) Di dunia

\section{B. Simulasi Backpropagation}

Sebelum melakukan simulasi prediksi, diperlukan untuk membagi data ke dalam data training dan data testing. Partisi data yang digunakan adalah untuk data training 80\% dan data testing 20\% [6].

Paramater yang digunakan pada simulasi Backpropagation adalah :

$\begin{array}{ll}\text { Learning rate } & : 0.2 \\ \text { Maximum epoch } & : 1000\end{array}$

Simulasi Backpropagation dapat dilihat pada Gambar 5, Gambar 6, dan Gambar 7. Pertama, inisialisasi matriks bobot dan terapkan pada data training menggunakan Backpropagation sampai epoch maksimal dan proses konvergensi dapat dilihat pada Gambar 5. Terlihat pada epoch awal, RMSE yang dihasilkan cukup besar. Pada proses optimisasi, RMSE menurun dan konvergen. Gambar 6 menunjukkan simulasi prediksi jumlah hotel dan restaurant yang tutup pada data training. Terlihat terdapat perbandingan dan error antara target dan output. Dari proses training sebanyak 1000 epoch, diperoleh matriks bobot optimal. Kemudian matriks bobot optimal diterapkan pada data testing. Gambar 7 menunjukkan simulasi prediksi jumlah hotel dan restaurant yang tutup pada data testing. Terlihat terdapat perbandingan dan error antara target dan output.

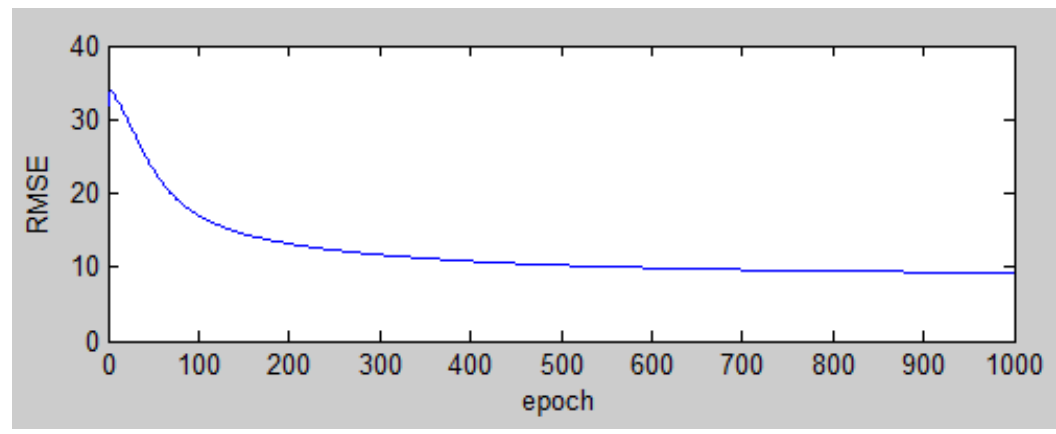

Gambar 5. Proses Konvergensi dari Backpropagation

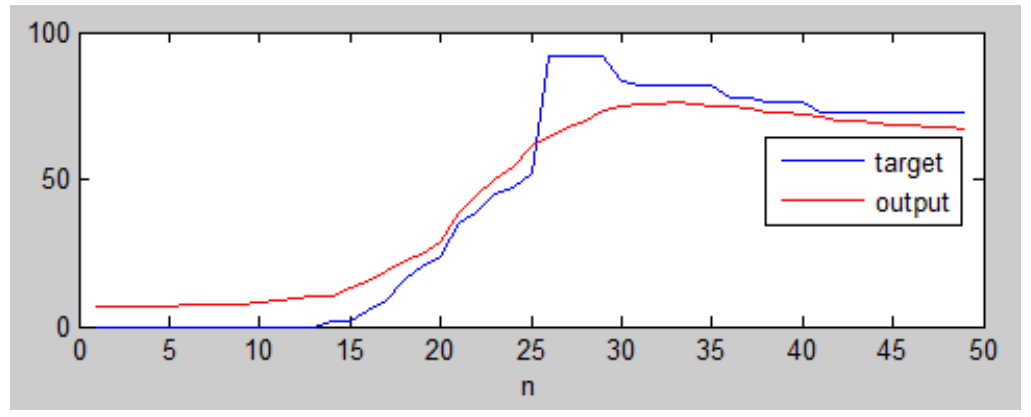

Gambar 6. Hasil prediksi jumlah hotel dan restaurant yang tutup di Jakarta pada data training 
INDEXIA: Informatic and Computational Intelegent Journal

Dinita Rahmalia, M. Yusak Anshori, Teguh Herlambang, Denis Fidita Karya - Prediksi Jumlah Hotel Dan Restaurant Tutup Akibat Dampak Covid-19 Menggunakan Backpropagation Dan Adaptive Neuro Fuzzy

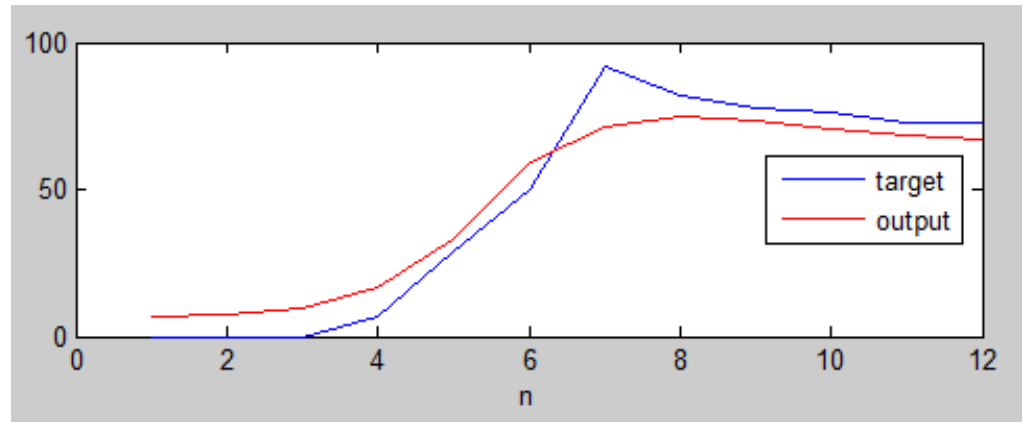

Gambar 7. Hasil prediksi jumlah hotel dan restaurant yang tutup di Jakarta pada data testing

Dari hasil simulasi, diperoleh prediksi dengan nilai Root of Mean Square Error (RMSE) pada (14) adalah 9,2422 pada data training dan 8,9419 pada data testing.

\section{Simulasi Adaptive Neuro Fuzzy}

Sebelum melakukan simulasi prediksi, diperlukan untuk membagi data ke dalam data training dan data testing. Partisi data yang digunakan adalah untuk data training 80\% dan data testing $20 \%$ [6].

Paramater yang digunakan pada Adaptive Neuro Fuzzy adalah :

Epoch maksimum

Jumlah fungsi keanggotaan

Jumlah rule

Jumlah linear parameter (consequent)

Jumlah nonlinear parameter (premise)
$: 30$

: 2 (setiap input)

$: 64$

$: 448$

$: 36$

The simulasi Adaptive Neuro Fuzzy dapat dilihat pada Gambar 8, Gambar 9, Gambar 10, dan Gambar 11. Terdapat dua fungsi keanggotaan yang digunakan yaitu 'kecil' dan 'besar'. Gambar 8 menunjukkan fungsi keanggotaan dari input yang telah dioptimisasi seperti jumlah korban positive Covid-19 di Jakarta, jumlah korban meninggal di Jakarta, jumlah korban positive Covid-19 di Indonesia, jumlah korban meninggal di Indonesia, jumlah korban positive Covid-19 di dunia, dan jumlah korban meninggal di dunia. Setiap fungsi keanggotaan menggunakan generalized bell (gbell) yang memiliki tiga parameter sebagai nonlinear parameter. Gambar 9 menunjukkan proses konvergensi dari RMSE. Terlihat pada epoch awal, RMSE yang dihasilkan cukup besar. Pada proses optimisasi, RMSE menurun dan konvergen. Gambar 10 menunjukkan simulasi prediksi jumlah hotel dan restaurant yang tutup pada data training. Terlihat terdapat perbandingan dan error antara target dan output. Dari proses training sebanyak 30 epoch, diperoleh parameter Adaptive Neuro Fuzzy yang optimal. Kemudian parameter Adaptive Neuro Fuzzy optimal diterapkan pada data testing. Gambar 11 menunjukkan simulasi prediksi jumlah hotel dan restaurant yang tutup pada data testing. Terlihat terdapat perbandingan dan error antara target dan output.

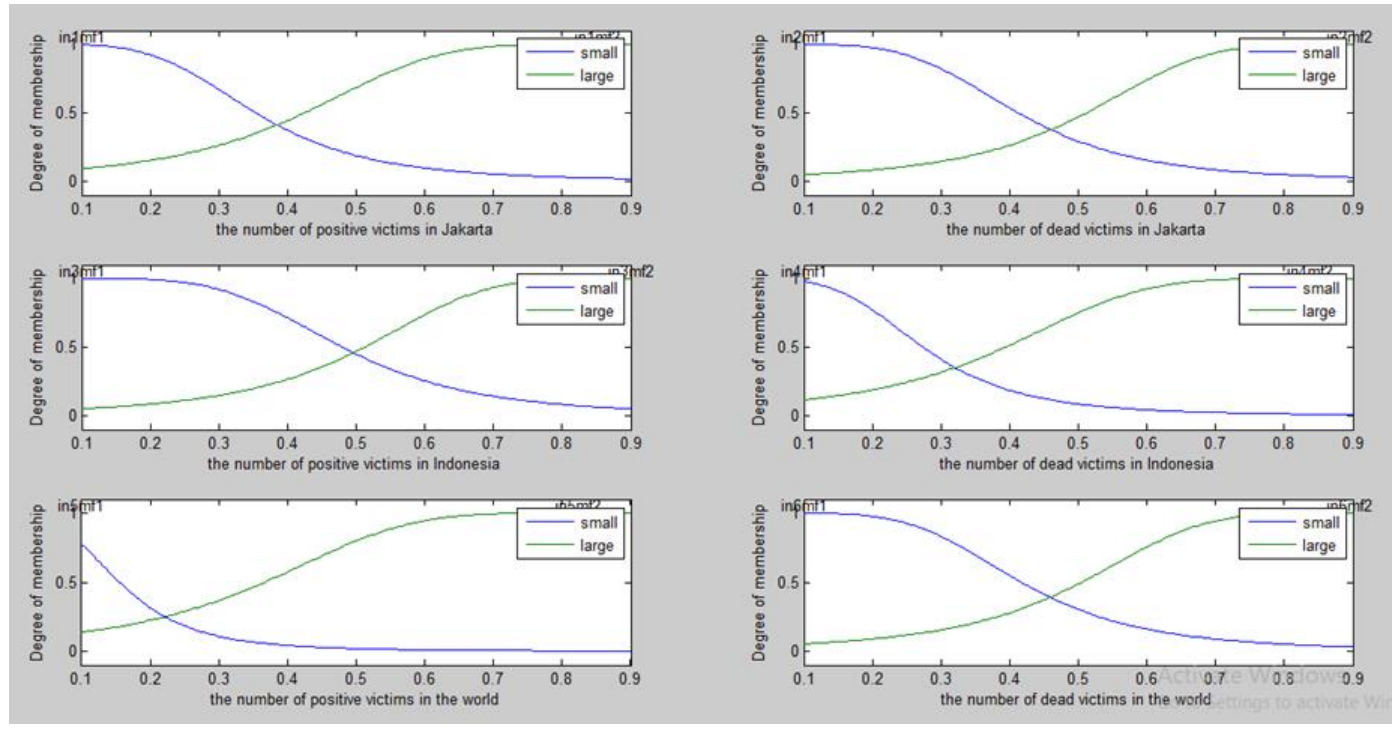

Gambar 8. Fungsi keanggotaan optimal dari setiap input 
INDEXIA: Informatic and Computational Intelegent Journal

Dinita Rahmalia, M. Yusak Anshori, Teguh Herlambang, Denis Fidita Karya - Prediksi Jumlah Hotel Dan Restaurant Tutup Akibat Dampak Covid-19 Menggunakan Backpropagation Dan Adaptive Neuro Fuzzy

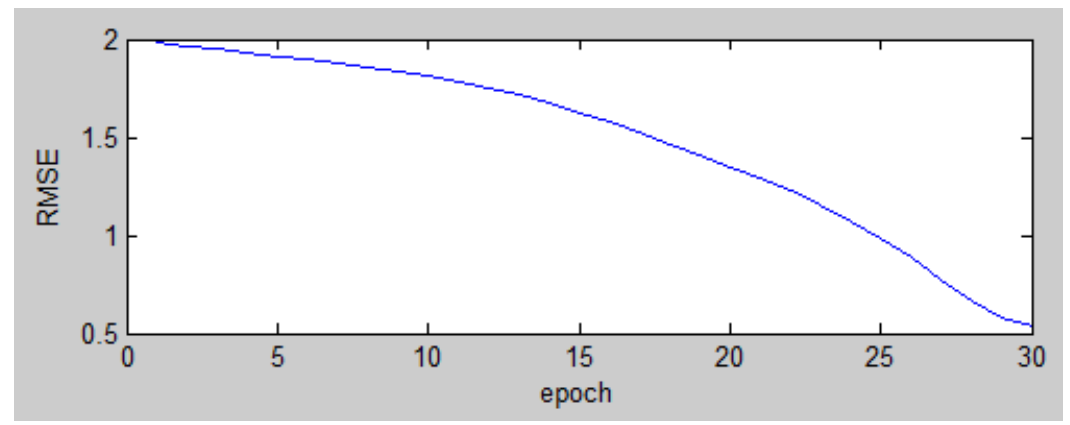

Gambar 9. Proses Konvergensi dari Adaptive Neuro Fuzzy

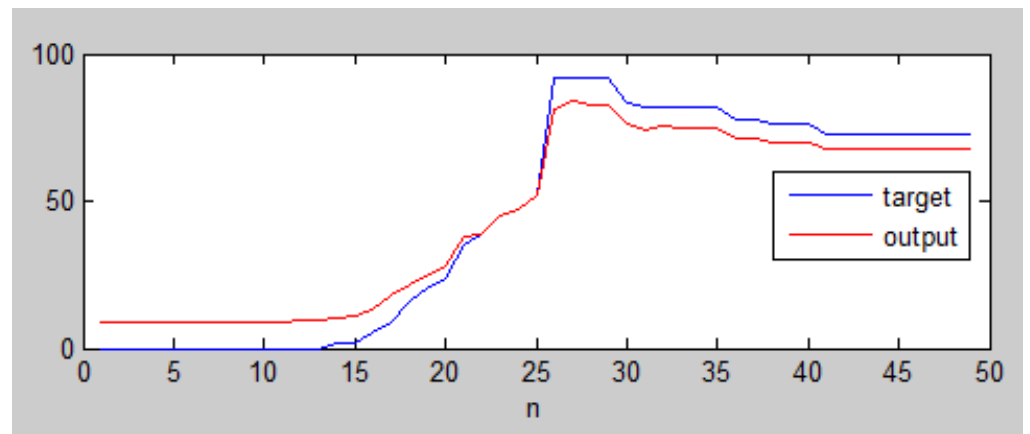

Gambar 10. Hasil prediksi jumlah hotel dan restaurant yang tutup di Jakarta pada data training

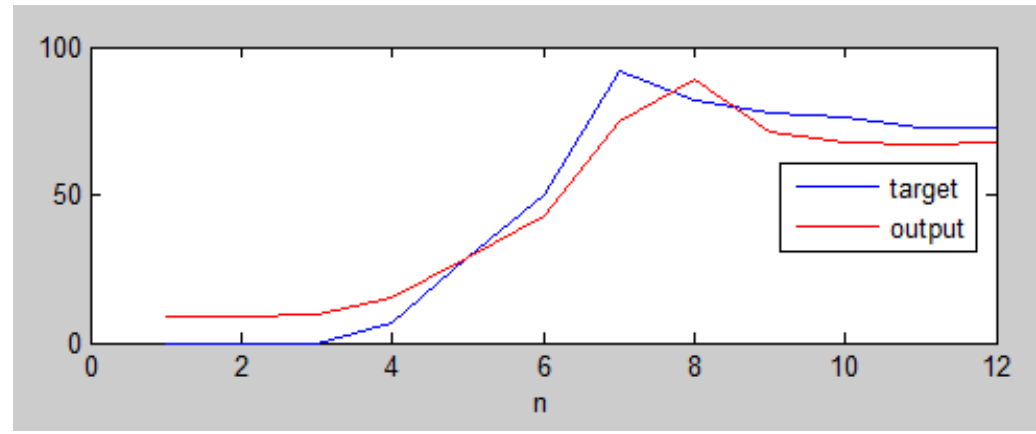

Gambar 11. Hasil prediksi jumlah hotel dan restaurant yang tutup di Jakarta pada data testing

Dari hasil simulasi, diperoleh prediksi dengan nilai Root of Mean Square Error (RMSE) pada (14) adalah 0,5324 pada data training dan 5,3198 pada data testing.

\section{KESIMPULAN}

Dalam membuat prediksi jumlah hotel dan restaurant yang tutup menggunakan Backpropagation dan Adaptive Neuro Fuzzy, diperlukan beberapa input seperti jumlah korban positive Covid-19 di Jakarta, jumlah korban meninggal di Jakarta, jumlah korban positive Covid-19 di Indonesia, jumlah korban meninggal di Indonesia, jumlah korban positive Covid-19 di dunia, dan jumlah korban meninggal di dunia.

Backpropagation dan Adaptive Neuro Fuzzy dapat membuat prediksi jumlah hotel dan restaurant tutup yang mendekati nilai target. Simulasi diterapkan dengan membagi dataset ke dalam data training (80\%) dan data testing (20\%). Dari simulasi Backpropagation, Backpropagation dapat menghasilkan prediksi jumlah hotel dan restaurant yang tutup pada data training dengan optimal RMSE adalah 9,2422 dan data testing dengan optimal RMSE adalah 8,9419. Dari simulasi Adaptive Neuro Fuzzy, Adaptive Neuro Fuzzy dapat membuat prediksi jumlah hotel dan restaurant yang tutup pada data training dengan optimal RMSE adalah 0,5324 dan testing data dengan optimal RMSE adalah 5,3198.

Pengembangan dari penelitian ini adalah membuat prediksi dan klasifikasi dengan data mining dan teknik 
INDEXIA: Informatic and Computational Intelegent Journal

Dinita Rahmalia, M. Yusak Anshori, Teguh Herlambang, Denis Fidita Karya - Prediksi Jumlah Hotel Dan Restaurant Tutup Akibat Dampak Covid-19 Menggunakan Backpropagation Dan Adaptive Neuro Fuzzy

machine learning.

\section{DAFTAR PUSTAKA}

[1] D. Rahmalia. (2018). Estimation of Exponential Smoothing Parameter on Pesticide Characteristic Forecast Using Ant Colony Optimization (ACO). Eksakta : Jurnal Ilmu-ilmu MIPA.[Online].18(1),hal. 56-63.

[2] M.S. Pradana, D. Rahmalia, E.D.A. Prahastini (2020). Peramalan Nilai Tukar Petani Kabupaten Lamongan dengan ARIMA. Jurnal Matematika.[Online].10(2), hal. 91-104.

[3] D. Rahmalia, N. Aini (2018). Pengaruh Korelasi Data pada Peramalan Suhu Udara Menggunakan Backpropagation Neural Network. Zeta-Math Journal.[Online].4(1), hal. 1-6.

[4] D. Rahmalia, M.S. Pradana (2019). Backpropagation Neural Network pada Data yang Tak Stationer (Studi Kasus : Jumlah Penderita Penyakit Ebola). Jurnal Riset dan Aplikasi Matematika (JRAM).[Online].3(1), hal. 32-42.

[5] D. Rahmalia, A. Rohmatulla (2019). Pengaruh Korelasi Data pada Peramalan Kelembaban Udara Menggunakan Adaptive Neuro Fuzzy Inference System. Applied Technology and Computing Science Journal.[Online].2(1),hal. 10-24.

[6] J. Han, M. Kamber, J. Pei, Data Mining Concepts and Techniques. USA: Elsevier, 2012

[7] L. Fausett, Fundamental of Neural Networks. USA: Prentice Hall, 1994

[8] M.Y. Anshori, D. Rahmalia, T. Herlambang. Comparison Backpropagation (BP) and Learning Vector Quantification (LVQ) on Classifying Price Range of Smartphone in Market. Dipresentasikan di ICCGANT.[Online].

[9] J. Shing, R. Jang. ANFIS : Adaptive Network Based Fuzzy Inference System. Dipresentasikan di IEEE Transaction on System, Man and Cybernetics

[10] D.F. Karya, P. Katias, T. Herlambang, D. Rahmalia. Development of Unscented Kalman Filter Algorithm for Stock Price Estimation. Dipresentasikan di ICCGANT.[Online].

[11] D. Rahmalia, M.S. Pradana, T. Herlambang (2020). Klasifikasi Multi Output pada Harga Smartphone Menggunakan Learning Vector Quantization (LVQ) dan Backpropagation (BP). Systemic Information System and Informatics Journal.[Online].6(2), hal. 14-19.

[12] M.Y. Anshori, D. Rahmalia, T. Herlambang, D.F. Karya. Optimizing Adaptive Neuro Fuzzy Inference System (ANFIS) Parameters Using Cuckoo Search (Case Study of World Crude Oil Price Estimation). Dipresentasikan di ICCGANT.[Online].

[13] D. Rahmalia, T. Herlambang. Comparison between Neural Network (NN) and Adaptive Neuro Fuzzy Inference System (ANFIS) on Sunlight Intensity Prediction Based on Air Temperature and Humidity. Dipresentasikan di ICCGANT.[Online].

[14] D. Rahmalia (2021). Optimizing the Membership Degree of Fuzzy Inference System (FIS) and Fuzzy Clustering Means (FCM) in Weather Data Using Firefly Algorithm. Cauchy Journal.[Online].6(4),hal. 169-180. 